\title{
A psicologia como procedimento de análise da moralidade nos escritos intermediários de Friedrich Nietzsche
}

\section{Psychology as a procedure for analysis of morality in intermediary writings of Friedrich Nietzsche}

\author{
Jelson Roberto de Oliveira* \\ Professor de filosofia na Pontifícia Universidade Católica do Paraná - PUC-PR, \\ Curitiba, Paraná, Brasil
}

\begin{abstract}
RESUMO
Pretende-se nesse artigo analisar a concepção de psicologia utilizada por Nietzsche nos escritos do chamado segundo período de sua produção (1876 a 1882). Anunciando-se como primeiro psicólogo da história, o filósofo alemão inaugura uma visão da psicologia associada à fisiologia, consolidando um procedimento fisio-psicológico de análise da origem dos sentimentos morais em vista da derrubada dos idealismos presentes na metafísica, na religião cristã e na arte romântica. Esse expediente remete a uma nova compreensão do próprio indivíduo humano a partir da noção de inocência do vir-a-ser.
\end{abstract}

Palavras-chave: Nietzsche, Psicologia, Fisiologia, Moralidade, Inocência.

\begin{abstract}
This article examines the notion of psychology used by Nietzsche in the writings of the so-called second period of his production (1876 to 1882). Announcing itself as the first psychologist of history, the German philosopher opens a view of psychology associated with physiology, consolidating a process of physio-psychological analysis of the origin of moral feelings in view of the defeat of idealism in the metaphysical, the Christian religion and romantic art. This procedure refers to a new understanding of the individual human from the notion of innocence becoming.
\end{abstract}

Keywords: Nietzsche, Psychology, Physiology, Morality, Innocence.

\section{I ntrodução}

Nos escritos chamados intermediários da filosofia nietzscheana, os quais compreendem o segundo período de sua produção e vão de 1876 a 1882, a psicologia aparece como procedimento de análise, com vistas à derrocada, dos três principais andaimes da cultura ocidental: a religião cristã, a arte romântica e a filosofia metafísica. Os escritos que constituem esse período estão marcados, assim, por uma concepção sui generis de "ciência" e demonstram o interesse do 


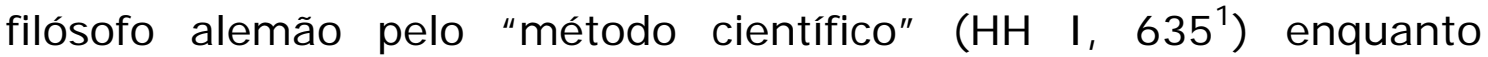
estratégia de crítica às bases idealistas desses andaimes culturais, com o fim de "impedir o triunfo da superstição e do contra-senso" (HHI, 635). Ora, aquilo que Nietzsche tem em vista quando fala de ciência está intimamente ligado àquilo que ele nomeia, já nas primeiras páginas de Humano, Demasiado Humano (livro que abre esse período intermediário), de procedimento histórico-fisiopsicológico: trata-se de uma perquirição a respeito do "homem", aquele que mede (Den Messenden, cf. AS, 21), o que avalia ${ }^{2}$ e cuja pretensão foi dominar e representar até "regiões que são inteiramente impossíveis" e que, por isso, só o fez como erro. Somado às outras obras publicadas nesse período (Aurora e A Gaia Ciência), os dois volumes de Humano, Demasiado Humano dão corpo a um procedimento que une, de um lado, filosofia e psicologia, e de outro, psicologia e fisiologia. Em outras palavras a Wissenschaft proposta por Nietzsche deve ser interpretada como uma tentativa de compreensão das "coisas humanas" e de interpretação da moralidade, da religião e do fenômeno artístico a partir dos sentimentos. Em outras palavras: a história dos sentimentos morais e a própria psicologia (como análise do fundo donde nascem esses sentimentos) são vistas como meios que, ao desvendarem as origens das valorações humanas, conduzirão ao desmonte das religiões e morais baseadas na metafísica. Esse é o uso estratégico feito por Nietzsche daquilo que ele entende e pratica como psicologia. Um uso decisivo para a construção de sua própria filosofia, principalmente no que diz respeito às principais teses de seu pensamento.

Esse novo expediente de análise da moralidade praticado como filosofia está ligado, assim, à noção de fisio-psicologia. O termo mesmo não é alheio a Nietzsche, tendo sido usado em Além de Bem e Mal, § 23, em cujo fragmento o filósofo fala de "uma autêntica fisio-psicologia" (Physio-Psychologie). Pode-se antecipar que o resultado a que chega o filósofo alemão através da aplicação desse procedimento é a asseveração de que a cultura não é nada mais do que um sintoma fisio-psicológico das construções (como manufaturas) humanas. Essa afirmação está ligada a uma reinterpretação do corpo, entendido não apenas em seu sentido físico ou biológico, mas como um processo de organização que interpõe uma hierarquia às forças que organizam provisoriamente a corporalidade em busca do crescimento do poder. Rompe-se, assim, o dualismo corpo-alma, para se pensar o corpo como grande razão, no qual aquilo que se chama de "alma" (ou consciência) não passa de um epifenômeno, uma pequena razão: "O corpo é uma grande razão, uma multiplicidade com um único sentido, uma guerra e uma paz, um rebanho e um pastor. Instrumento de teu corpo é, também, a tua pequena razão, meu irmão, à qual chamas 'espírito', pequeno instrumento e brinquedo da tua grande razão" (ZA, II, Dos 
desprezadores do corpo). Como grande razão o corpo é o instrumento mais complexo das múltiplas pulsões vitais de todas as coisas e ele deve ser o lugar donde derivam as condições de veracidade das coisas e serve mesmo de definição para o humano, já que o indivíduo mesmo é apresentado como um resultado dessa luta das forças que se dão no âmbito fisiológico e também psicológico.

\section{Nietzsche, o primeiro psicólogo da história}

Nietzsche compreende e utiliza a psicologia, nesses escritos, como instrumento de dissecação dos idealismos. Na esteira da influência dos Essais de Psychologie Contemporaine, de Paul Bourget, publicado em várias partes desde 1881, e sua conexão entre psicologia e moralidade, Nietzsche estabelece a tarefa da psicologia, entendida como uma arte da interpretação esboçada como análise e avaliação das "coisas humanas". Para tanto, como "estudo da alma" ( $\mathrm{HH} \mathrm{I,} \mathrm{36)}$ a psicologia disseca a origem dos idealismos (presentes na metafísica, na religião e na arte) como erros e preconceitos, levando não à negação da existência, mas à sua afirmação. A psicologia, assim, se torna o procedimento mesmo da filosofia nietzscheana: "nos meus livros fala um psicólogo, que não tem igual, eis porventura a primeira constatação a que chega um bom leitor, tal como eu o mereço [...]" (EH, Porque escrevo tão bons, 5). Explicitamente influenciado pelos moralistas franceses, Nietzsche pergunta no prólogo de Humano, Demasiado Humano: “Mas onde existem hoje psicólogos? Na França, certamente; talvez na Rússia; não na Alemanha, com certeza" $(\S 8)^{3}$. Nietzsche parece pretender preencher esse vazio.

Mas o que o filósofo entendia pelo termo psicologia? Não algo distinto da fisiologia, como um conhecimento sobre a alma, a subjetividade ou mesmo a psique humana, tal como esse ramo da ciência vinha sendo praticado na modernidade, baseada na relação entre o psíquico e o consciente, ou seja, como uma ciência da consciência subjetiva e, portanto, da subjetividade. Certo é que Nietzsche não desconhecia esse uso moderno, mas também não o confirmara, já que ele estaria ligado ao trabalho metafísico por ele denunciado ${ }^{4}$.

O tema aparece como decisivo na obra de Nietzsche por seu uso estratégico no combate à metafísica e está ligado à sua "arte da inferência retroativa" (GIACÓIA JÚNIOR, 2006, p. 10), ou seja, a sua busca pelas condições que deram origem aos fenômenos morais. Essa tarefa da psicologia como crítica da metafísica está embasada, portanto, num programa de destruição dos fundamentos metafísicos da moralidade, tais como a noção de consciência como unidade subjetiva e seu primado em relação ao corpo e àquilo que poderia ser chamado de inconsciente. É o que Nietzsche expressa no parágrafo 23 de Além de Bem e Mal, nas seguintes palavras: "Toda psicologia, até o momento, tem estado presa a preconceitos e temores morais: 
não ousou descer às profundezas. Compreendê-la como morfologia e teoria da evolução da vontade de poder, tal como faço - isto é algo que ninguém tocou sequer em pensamento" (BM, 23). Nietzsche pretende, justamente, estudar essas "profundezas" que se encontram por baixo das avaliações morais que se cristalizam como preconceitos - e nisso ele se anuncia como primeiro, pelo inédito instrumento que nessa passagem ganha os contornos da vontade de poder.

Esse mesmo olhar para o "mais profundo" aparece já em Humano, Demasiado Humano: “Enquanto livro para 'espíritos livres', fala nele algo da frieza quase serena e curiosa do psicólogo [...]", escreve Nietzsche no prólogo do segundo volume dessa obra (Miscelânea de Opiniões e Sentenças, Prólogo, 1), escrito em 1886. Nessa época o filósofo reconhece a obra como uma psicologia que desvela o que há "por debaixo" e "por trás" da moralidade e do "autotratamento antiromântico" (OS, Prólogo, 2) que Nietzsche pretende perpetrar como parte do rompimento com a primeira fase de seu pensamento. Pretendendo "prosseguir sozinho" (Prólogo, 3), a partir de uma "primeira suspeita contra a música romântica", Nietzsche confessa ter feito nessa obra um "combate contra a anti-científica tendência fundamental de todo pessimismo romântico a exagerar, a interpretar experiências pessoais singulares como juízos universais" (Prólogo, 5). Para isso foi preciso "inverter" seu olhar, alterar seu ponto de vista contra o "pessimismo romântico" (OS, Prólogo $7^{5}$ ), ou seja, contra a filosofia de Schopenhauer e a música de Wagner.

Para essa tarefa, portanto, faz-se necessário um uso interdisciplinar que junte não apenas a psicologia com a morfologia e com a fisiologia, mas também com a história, a cultura, a linguística, a literatura, a medicina e várias outras áreas do conhecimento, tal como Nietzsche reiteradamente faz uso.

Ao se autoproclamar o primeiro psicólogo da história ${ }^{6}$, portanto, Nietzsche evoca essa "originalidade" no uso do termo psicologia, desvencilhando-o dos fundamentos metafísicos para usá-lo - ao contrário - como crítica da metafísica, mormente a separação entre alma e corpo e a dissolução da crença na unidade consciente da alma e do "eu". O uso do termo, assim, remete a uma análise crítica que alia história, arte e perspectivismo para esboçar uma destruição dos privilégios da consciência e do dualismo que marcara a compreensão dos fenômenos humanos. É isso o que faria agora a psicologia a "senhora das ciências" (BM, 23), destituindo a teologia desse posto. Retirando o papel representado pela ciência de Deus, coloca-se a psicologia no centro e se chega ao humano em sentido integral, ou seja, ao humano no qual todas as funções psíquicas e fisiológicas seriam reconhecidas como independentes da consciência e não submetidas unicamente ao seu domínio.

Num dos textos mais fecundos para a compreensão da sua psicologia como crítica da consciência, Nietzsche escreve: "Poderíamos, com 
efeito, pensar, sentir, querer, recordar-nos, poderíamos igualmente agir em todo sentido da palavra: e a despeito disso, não seria preciso que tudo isso nos entrasse na consciência (como se diz, em imagem)" (GC, 354). O que Nietzsche tem como convicção é que as funções psíquicas e fisiológicas podem existir sem 0 apelo à consciência, ou seja, sem a pretendida unidade do "eu" que transforma em representação todo acontecimento fisio-psicológico. É nisso, justamente, que a consciência se torna supérflua: "Para que em geral consciência, se no principal ela é supérflua?" (GC, 354). Só pela necessidade de comunicação, Nietzsche mesmo reponde. Ou seja, só pelo instinto gregário que simplifica e torna familiares (e, portanto, empobrecido) todas as vivências, é que a consciência se faz necessária. Ela é a parte mais fraca e mais superficial porque reduz essas vivências aos signos de comunicação ditos através dos recursos linguísticos. Isso explica a importância do contraconceito de vivências utilizado por Nietzsche nas obras desse segundo período: ele evoca o abandono do esquema consciência-linguagem-sociabilidade no qual o que chega à consciência são as representações exigidas pela necessidade de comunicação, desligando racionalidade de consciência para explicitar a importância do que não chega à consciência, daquilo que permanece multifacetado, semiconsciente, inconsciente e profundo a tal ponto que não pode ser transformado em palavra. As vivências, portanto, são a "descoberta" dessa psicologia praticada por Nietzsche e que está amparada na ideia de que toda comunicação não passa de um "tornar comum", ou seja, da vulgarização, da supressão da diferença e daquilo que é próprio e autêntico. No fundamento das relações sociais e comunitárias que ligam o "eu" ao "outro" estaria, portanto, um erro empobrecedor e reducionista que "bloqueia as vias de acesso ao próprio, ao si mesmo, tornando a consciência e a linguagem reféns do gregário, do identitário, do inautêntico" (GIACÓIA JÚNIOR, 2006, p. 40).

Um bom exemplo desse procedimento é o tratamento dado por Nietzsche ao conceito de amizade, tema frequente nos escritos desse segundo período, e utilizado como instrumento de crítica à moral da compaixão ${ }^{7}$ : trata-se de um resultado maduro da utilização da psicologia como análise da moralidade. Isso porque a moral da compaixão de tipo schopenhauriana (mas também cristã) é interpretada por Nietzsche como embasada numa noção de "eu" que leva à anulação de si mesmo pelo movimento da consciência (conhecer a si mesmo) e da perspectiva do rebanho. A amizade, ao contrário, estaria baseada na capacidade de conquista de si e de compartilhamento de vivências que, na medida em que permanecem alheias à consciência, não estão mais pautadas pelas necessidades gregárias que marcam os requisitos, regras e costumes da moralidade ocidental. Na medida em que está firmada no equívoco da 
consciência, essa moralidade conduz à negação daquilo que é mais rico e mais próprio em cada indivíduo:

\begin{abstract}
Meu pensamento, como se vê, é que a consciência não faz parte realmente da existência individual do ser humano, mas antes daquilo que nele é natureza comunitária e gregária; que, em consequência, apenas em ligação com a utilidade comunitária e gregária ela se desenvolveu sutilmente, e que, portanto, cada um de nós, com toda a vontade que tenha de entender a si próprio da maneira mais individual possível, de "conhecer a si mesmo", sempre traz à consciência justamente o que não possui de individual, o que nele é "médio" [...] Todas as nossas ações, no fundo, são pessoais de maneira incomparável, únicas, ilimitadamente individuais, não há dúvida; mas, tão logo as traduzimos para a consciência, não parecem mais sê-lo... (GC, 354)
\end{abstract}

Na medida em que a comunidade e o instinto gregário continuem vigorando como critério ético por excelência, como exige a ética da compaixão, continuará grassando em termos morais a anulação das vivências e daquilo que há de mais "individual" do humano e que lhe caracteriza radicalmente. Ao optar pelo primado da consciência, a moralidade desconhece o humano e se eleva ao que é corrompido, falso, superficial e generalizado. Ao contrário, ao projetar uma ética da amizade, Nietzsche vê a necessidade de implementar uma nova visão do humano (para o que necessita de uma nova psicologia), que integre as vivências mais próprias que continuam incomunicáveis (sob o risco de se tornarem vulgares e portanto, enganos a respeito de si mesmo) em cada indivíduo (e não mais no próximo ou mesmo no "homem" em sentido geral). A psicologia de Nietzsche está na base, portanto, de seu projeto de uma ética da amizade porque, ao destituir a moral de seus fundamentos metafísicos, ela abre a possibilidade de pensar as relações humanas e o próprio humano para além do princípio gregário do ethos.

Esse é um resultado de sua estratégia de "médico da cultura" expressão liga o filósofo ao personagem que diagnostica a relação entre filosofia e saúde (porque vivenciou "muitas saúdes", conforme o prólogo de A Gaia Ciência, § 3) para experimentar com profundidade e temeraridade a possibilidade de uma nova moralidade. Nietzsche pretende que o filósofo, nesse sentido, seja um "médico filosófico" (GC, Prólogo, 2) que possa desvendar as relações que deram ensejo à moralidade gregária como resultado da saúde ou da doença de seus próprios formuladores e arautos. Isso porque toda pretensão de "verdade" esconde a condição de saúde do seu intérprete:

os grandes filósofos não tem consciência de que falam apenas de si mesmos - eles têm a pretensão de tratar 'da verdade'- quando, no fundo, trata-se apenas deles mesmos. 
Ou melhor, neles, o impulso mais violento vem à luz com a maior falta de pudor e a inocência de um impulso fundamental: ele quer se tornar soberano e, se possível, o objetivo de todas as coisas, de todo acontecimento! O filósofo não é senão uma espécie de ocasião e de sorte para que o impulso consiga finalmente tomar a palavra [...] Fica claro aqui que é o impulso soberano quem fala, e ele é mais forte do que o homem. A cada vez o impulso acredita ser o detentor da verdade e do conceito supremo do 'homem' [Mensch] (KSA 10, 7 [62], de 1883, p. 262)

Como resultado da sua tarefa como "médico filosófico", Nietzsche transforma o "homem" - ou o "humano" - no tema (ou no problema) psicológico por excelência nesse segundo período de sua produção e sua tarefa é desvelar a "química das representações dos sentimentos" ( $\mathrm{HH} \mathrm{I}, 1)$ que fundam os chamados fatos morais, já que as representações são criadas a partir do mundo, como "coisas humanas" interpretadas. Trata-se, pois, de uma análise crítica implementada como estratégia filosófica para esquadrinhamento das "coisas humanas". Por isso, a psicologia passa a ser definida como "a ciência que indaga a origem e a história dos chamados sentimentos morais e que, ao progredir, tem de expor e resolver os emaranhados problemas sociológicos" ( $\mathrm{HH} \mathrm{I}, 37)$. É isso, precisamente, que Nietzsche entende e pratica como psicologia e que, de resto, está ligada à sua fisiologia, já que se rompe, nessa visão do humano, o dualismo corpo/espírito que até então também separava as ciências do espírito das ciências do corpo e essas das ciências da natureza.

\section{Uma psicologia que é também fisiologia}

Quanto à fisiologia, embora Nietzsche use o termo desde $1872^{9}$ (sua primeira aparição se dá no parágrafo 4 , de Sobre o Futuro dos nossos estabelecimentos de ensino) é só a partir de Humano, Demasiado Humano que o conceito ganha importância, vindo a se apresentar com frequência nas obras do último período de sua produção, principalmente em fragmentos póstumos de 1888 e 1889. A relevância, entretanto, da fisiologia para Nietzsche é claramente transversal e remete a seus primeiros escritos, por exemplo, no que diz respeito aos impulsos dionisíaco e apolíneo em torno do Nascimento da Tragédia e da desordem de impulsos presente em Sócrates, o primeiro décadent que levou à morte a Tragédia grega. Entretanto, o vocábulo não pode ser compreendido independente daquilo que Nietzsche chama de psicologia, e que, como se viu, está embasada num rompimento do tradicional dualismo "corpo" e "alma". Entre os sentidos da palavra fisiologia em Nietzsche está tanto a compreensão do seu uso corrente enquanto a parte da biologia que estuda as atividades vitais, quanto um sentido lato, ligado aos processos de lutas dos quanta de poder em busca de expansão. 
Quanto ao segundo sentido, ele será corrente no último período da produção de Nietzsche, enquanto no segundo período prevalece um uso do termo para a determinação do soma, ou seja, para as funções orgânicas e também às afecções que nascem do corpo, entendido como um conjunto mais ou menos organizado de forças e impulsos em cuja expressão se efetiva aquilo que o filósofo entende como vida, ou seja, a luta constante dos impulsos em busca do poder, em longos exercícios de superação e autosuperação. ${ }^{10}$

Se Nietzsche efetiva uma transfiguração naquilo que se entende como psicologia, esse procedimento também impacta sobre a sua compreensão de fisiologia: o corpo não é entendido pelo filósofo a partir da visão empírico-radical do sensível tal como postulada pelo materialismo ou como campo pretensamente neutro proclamado pelos lógicos e físicos modernos. Para Nietzsche esse materialismo seria mais um efeito das crenças e preconceitos metafísicos por estar alicerçado em ancestrais artigos de fé que tornam os corpos nada mais do que composições de moléculas e átomos, representações de partículas elementares que formariam a matéria. Essa perspectiva seria uma mera continuação das doutrinas cristãs, do platonismo, do cartesianismo e, no limite, de toda a prática filosófica e científica ocidental que vê no conjunto da realidade a permanência de um fundamento unitário elementar que explicaria os fenômenos da realidade através da inteligibilidade de um sujeito-eu-alma. A física e a fisiologia apegadas a essa tendência seriam, para Nietzsche, reféns ainda da metafísica, já que não haveria uma "realidade em si" disponível para o conhecimento.

A crença do atomismo materialista na unidade e na substância é equivalente à crença na alma como algo indivisível, simples e eterna que subsiste como unidade do "eu", em contraposição ao que é sensível e transitório presente no corpo. Nem corpo e nem alma tem qualquer unidade ou substância elementar porque ambos se caracterizam por relações de forças e irradiação de efeitos sobre outras forças. Alma e átomo seriam apenas preconceitos e erros de uma metafísica da unidade da qual Nietzsche tenta se distanciar. O papel do novo psicólogo - que é também um fisiólogo, na medida em que os limites de corpo e alma são distendidos - é novamente inventar (erfinden) para poder descobrir (finden) alguma resposta:

Ao pôr um fim à superstição que até agora vicejou, com luxúria quase tropical, em torno à representação da alma, é como se o novo psicólogo se lançasse em um novo ermo e uma nova desconfiança - para os velhos psicólogos, as coisas talvez fossem mais cômodas e alegres; mas afinal ele vê que precisamente por isso está condenado também à invenção [Erfinden] - e, quem sabe?, à descoberta [Finden]. (BM, 12) 
A nova tarefa de invenção é explicitada por Nietzsche pela hipótese de compreensão do corpo como um complexo campo de fenômenos muito mais interessante e rico para o filósofo-psicólogo porque não atua mais sob as faculdades distintas de querer (Vontade), sentir (Sentimento), pensar (Racionalidade) e se deixar afetar (Afecções). Como Erfinden a hipótese se torna um experimento e abre as possibilidades de uma nova compreensão (muito mais complexa) da fisiologia e da própria psicologia. No corpo, então, a razão não é mais do que um entre os demais "instrumentos" ou "faculdades", um órgão secundário que se tornou dirigente por força da necessidade gregária de comunicação.

Portanto, para Nietzsche o corpo não é um sistema ou esquema carregado de teleologia que explicita a dualidade pensante-corpóreo. O uso do alemão Leib está baseado no rompimento do tradicional dualismo corpo e alma e ao mesmo tempo num alargamento da compreensão de corpo, que não é apenas a parte corpóreo-material, mas inclui os afetos, os pensamentos (a razão), os impulsos e os instintos. Como ultrapassamento da compreensão vulgata, o corpo aparece como o lugar da autoexperimentação, ele é o labirinto no qual o indivíduo se vê em luta consigo mesmo e que serve de "fio condutor" (ZA, Dos desprezados do corpo) para a compreensão dos estados de luta que fundam a existência como um todo. Nessa noção de existência estão incluídos os demais seres vivos, com os quais o indivíduo humano partilha a mesma condição orgânica que funda e extrapola o limite da consciência (pequena razão) e que Nietzsche chama de instintos, pulsões ou impulsos.

Nessa medida, o corpo não é apresentado como um todo organizado segundo os interesses da razão, mas "surge sobretudo como a consequência fenomênica da autoafirmação de seres singulares" (MARQUES, 2003, p. 167) no qual falta um "regente", ou seja, um sujeito consciente e responsável. O corpo é o sinal da "dissolução da unidade" impetrada pelo procedimento fisio-psicológico que não vê distinção entre o corpóreo e o psíquico e que implementa ações inocentes no reino das puras interpretações como fluência de estados complexos de forças que se efetivam segundo os interesses do poder. Além disso, é bom lembrar que é essa noção estendida de corpo que serve a Nietzsche de base para a postulação avaliativa em expressões como "forte", "fraco", "doente" e/ou "saudável", já que todos os conhecimentos e morais criadas pelo "homem" não são mais do que derivações e sintomas desses estados corporais subjacentes. Nietzsche entende que "as ideias não são outra coisa que reflexos da história da alma, documentos, produtos expressivos, sintomas" (FINK, 1989, p. 52). ${ }^{11}$ Isso se expressa, por exemplo, em A Gaia Ciência, 179: "Pensamentos são as sombras dos nossos sentimentos - sempre mais obscuros, mais vazios, mais simples do que estes". 


\section{O procedimento fisio-psicológico de análise da moralidade}

Sendo assim, tanto no caso da psicologia quanto da fisiologia, Nietzsche as utiliza, por um lado, como instrumentos de análise da moralidade, na medida em que servem de denúncia dos erros e dos preconceitos dos idealismos que levaram à degeneração moral como processo de decomposição que se iniciou a partir das implicações fisiológicas. Por outro lado, são elas os instrumentos que podem concorrer para a elevação do humano e o fortalecimento da vida. Assim, com os dois termos, chega-se a dois processos: um de denúncia da moralidade que encurta a vida e outro de apontamentos das possibilidades de seu fortalecimento. Ambos os artifícios, entretanto, efetivam-se de forma articulada, concretizando o caráter fisio-psicológico desse procedimento.

Esse procedimento, o qual mais tarde será batizado de "genealógico", apresenta-se nesses escritos como "apontamentos" e "indícios". Não à toa, o título do segundo capítulo de Humano, Demasiado Humano é justamente Contribuição à história dos sentimentos morais e o primeiro parágrafo ( $\S 35$ ) anuncia as Vantagens da observação psicológica, destacando que, para a história desses sentimentos, é preciso levar em conta os subsídios fornecidos pela psicologia. No terceiro capítulo o alvo dessa observação é a vida religiosa, em seguida a arte, a cultura, as relações interpessoais, o Estado e, enfim, o indivíduo consigo mesmo: todo o livro deve ser entendido como um projeto de observação científica das várias facetas da vida humana. E é isso o que, no limite, caracteriza o procedimento psicológico praticado por Nietzsche nesse período.

Explicitamente influenciado por seu amigo Paul Rée, o qual publicara nessa época Observações Psicológicas (1885) e encontrava-se em processo de elaboração do seu Sobre a origem dos sentimentos morais, Nietzsche esboça no segundo capítulo de Humano, Demasiado Humano a necessidade da dissecação fisio-psicológica como instrumento de acesso à origem dos sentimentos morais. Escreve ele:

Ou haveria um contrapeso à tese de que a observação psicológica se inclui entre os atrativos e meios de salvação e alívio da existência? Não deveríamos estar bastante convencidos das desagradáveis consequências dessa arte, para dela afastar intencionalmente o olhar dos que se educam? De fato, uma fé cega na bondade da natureza humana, uma arraigada aversão à análise das ações humanas, uma espécie de pudor frente à nudez da alma podem realmente ser mais desejáveis para a felicidade geral de um homem do que o atributo da penetração psicológica $[\ldots] .(\mathrm{HH} \mathrm{I}, 36)$ 
Essa tarefa de observação psicológica é árdua e traz muitos dissabores, mas ainda assim é necessária para que se evite os erros que fizeram ver bondade na natureza por medo de penetrar nos recônditos da alma humana. Entre os perigos indesejados dessa observação científica do que é humano, está a ausência de um sentido fixo para a verdade, cuja exigência faz com que o pesquisador, como experimentador, consiga lidar com a falta de sentido e as várias perspectivas de uma tarefa que pode não garantir nenhuma segurança. Em outras palavras: a ciência de Nietzsche exige a capacidade de lidar com o perspectivismo de todo conhecimento. "Portanto: se a observação psicológica traz mais utilidade ou desvantagem aos homens permanece ainda sem resposta; mas certamente é necessária, pois a ciência não pode passar sem ela", afirma Nietzsche no $\S 38$ de Humano, Demasiado Humano.

A fisio-psicologia é para Nietzsche um instrumento de "dissecação psicológica" que, através de suas "pinças e bisturis", caracteriza o fazer científico por cujo artifício se realiza a observação dos fenômenos morais. Ela é a "ciência que indaga a origem e a história dos chamados sentimentos morais e que, ao progredir, tem de expor e resolver os emaranhados problemas sociológicos" $(\mathrm{HH} \mathrm{I}, 37)$. Nietzsche é claro a respeito da novidade desse filosofar histórico que é também um filosofar fisio-psicológico, já que, segundo ele, "a velha filosofia não conhece em absoluto estes últimos, e com precárias evasivas sempre escapou à investigação sobre a origem e a história dos sentimentos morais".

Mas o que seriam esses "sentimentos morais" que devem ser desvelados pela fisio-psicologia? Nada mais do que aquilo em virtude do que "tornamos alguém responsável por seus atos" ( $\mathrm{HH} \mathrm{I}, 39)$ e que Nietzsche identifica na ilusão psicológica do livre-arbítrio e na repressão do desejo de autofruição que estaria na base dos sentimentos morais. Vê-se dessa forma como Nietzsche chega à crítica fisio-psicológica da moral da compaixão, já que tanto a vontade livre quanto a anulação de si em função do outro são identificadas como premissas dessa moral que compartilha dor e sofrimento como parte constituinte da experiência vital que é, sobretudo, uma experiência de culpa.

O procedimento fisio-psicológico coloca em questão a premissa primeira da moral da compaixão de Schopenhauer e de todo o cristianismo conforme essa é interpretada por Nietzsche: a responsabilidade, em cujas bases se apóiam tanto a crença na racionalidade quanto na liberdade da ação (a crença no livre-arbítrio é que enraíza o processo de culpabilização moral do humano e do mundo). Ora, essa tese não está reduzida ao âmbito da consciência moral. A psicologia, na medida em que dá acesso à "base obscura" das pulsões que engendram todas as ações humanas, adentra 0 
âmbito da pura necessidade (entendida aqui como ausência completa de liberdade).

Então, pela psicologia, desvela-se algo muito mais "fundamental" do que aquilo que se apresenta e se mede enquanto moralidade porque por ela se reconhece as forças sem sentido e/ ou finalidade que guiam as ações humanas e que, como tal, não podem levar à culpa ou punição, nem mesmo à responsabilidade do humano frente a seus atos, já que não estamos no âmbito das "escolhas livres". É esse o processo de criação dos sentimentos morais descrito de forma clara, em três fases, no $\S 39$ de Humano, Demasiado Humano: (a) a invenção e o esquecimento dos motivos da definição de algo como bom ou como mau; (b) a definição dos atos como ambíguos a partir dessa definição; a identificação do "homem" (em seu "próprio ser" e não mais através de seus atos isolados) como bom ou mau, tornando-o responsável por seus atos; (c) até que se chega à conclusão de que isso não passa da "história de um erro, o erro da responsabilidade, que se baseia no erro do livre-arbítrio".

\section{A crítica à arte romântica}

No que tange à noção de arte presente nos escritos desse período Nietzsche utiliza esse mesmo procedimento fisio-psicológico para denunciar a aura metafísica que legitimou a arte como fundamentação e justificação da existência (vale lembrar que era esse o seu projeto em 0 Nascimento da Tragédia e nos escritos dos primeiros anos de 1870, quando o filósofo alimentava ainda a esperança de renovação da cultura alemã através da arte). Agora, nesse período intermediário, Nietzsche destaca o papel da arte para o alívio da existência, a conquista da leveza que torna a vida suportável. Ora, a idéia de leveza está ligada à capacidade de carregar o peso existencial: o que é leve depende, diretamente, da força capaz de suportar a vida. A arte torna a vida suportável porque faz o humano adentrar com mais força na vida, ela potencializa as forças e capacita o humano a enfrentar o peso da vida.

A denúncia de Nietzsche é que a arte foi considerada legítima apenas na medida em que distanciou da vida, em que criou uma realidade à parte para onde todo artista deveria se dirigir se quisesse obter alguma legitimidade. Essa pretensa validade da arte estaria ligada à sua capacidade de negar a existência, de elevar acima dela, de alimentar esperanças ultra-mundanas na medida em que a própria vida se rendeu ao jogo da culpa e do ressentimento. De fundar idealismos também na arte - a soberana tarefa do romantismo. Para isso fora preciso, por exemplo, negar que a arte vem-a-ser, e vesti-la de uma sacralidade metafísica que pretensamente the garante alguma licitude por aproximá-la da religião.

A arte, para parecer legítima, passou a demonstrar o seu valor na medida em que nega a realidade existencial em benefício de uma 
realidade supra-sensível. É o que Nietzsche escreve, por exemplo, no aforismo 145 de Humano, demasiado humano: "o valor da arte estaria na sua gênese milagrosa e a sua perfeição, no fato de que não tenha vindo-a-ser". Ou ainda um pouco mais à frente, no aforismo 146, no qual destaca que "o artista não quer abrir mão do fantástico, mítico, incerto, extremo, simbólico, da superestimação da pessoa, da crença em algo miraculoso no gênio". Ou seja, vestindo-se do milagroso e do fantástico, a arte continuou ainda em terreno religioso, erguendo-se sobre os idealismos que agora, passaram a the dar legitimidade. A arte vale na medida em que esconde o seu vir-aser existencial e revela uma origem milagrosa, distante da vida.

Essa é, por exemplo, a crença que se alimenta na inspiração: "todos os grandes foram grandes trabalhadores, incansáveis não apenas no inventar, mas também no rejeitar, eleger, remodelar e ordenar" $(\mathrm{HDH}, 155)$. Os grandes artistas são grandes trabalhadores da arte e sua grandiosidade está em lapidar sua própria arte e a si mesmos nesse processo de forma incansável. A inspiração, na medida em que aparece como algo miraculoso e repentino, nada mais faz do que esconder a diligente tarefa e o esforço constante necessário para a produção artística. Para Nietzsche, "o capital se acumulou, não caiu do céu" (HDH, 156).

Assim, o gênio estaria sempre pensado como alguém distante de nós ( $\mathrm{HDH}, 162)$, um misantropo escondido sob os véus de uma gloriosa aproximação do divino e do miraculoso. Do contrário ele não teria legitimidade e aceitação. Em outras palavras, não seria artista e sua obra não seria arte. Nietzsche denuncia, com o seu procedimento histórico-fisio-psicológico, que todas as grandezas de um artista foram adquiridas, ainda que eles gostem de esconder esse fato $(\mathrm{HDH}$, 163). A intenção seria esconder as qualidades humanas que deram origem à obra, bem como a temática existencial que lhe confere o status de arte. O artista é um resultado da confluência de muitas oportunidades e esforços, tematizados pelo filósofo alemão no parágrafo 164 de Humano, demasiado humano: "para os grandes espíritos é provavelmente mais útil que eles se dêem conta de sua força e da origem desta, que apreendam as qualidades puramente humanas que neles confluíram, as felizes circunstâncias que ali se juntaram: energia incessante, dedicação resoluta a certos fins, grande coragem pessoal; e também a fortuna de uma educação que logo ofereceu os melhores mestres, modelos e métodos".

Agora, para Nietzsche, é a experimentação dessas condições vitais humanas, demasiado humanas que serve de critério para o artista e a sua arte. Só a vivência mais íntima e indizível das paixões e dos dramas por parte do artista faria dele mesmo um artista, não importa o quanto de invenção, milagre e fumaça de incenso ainda persistam na arte. Isso não passaria de uma herança religiosa ainda presente 
na arte: que ela tenha uma origem divina, próxima dos mistérios que elevam para fora da vida.

A visão romântica da arte tentara, ainda, passar a imagem de que ela subsiste eternamente, como algo que tem validade universal e, para que seja reconhecida como arte, dê expressão a sentimentos e ações imutáveis e fixos. Ora, a verdadeira arte, na medida em que nasce da vida, não capta a não ser o que é passageiro, a experiência mais própria do humano que se apresenta naquele momento, naquela vida, naquele lugar específico no qual a experiência humana se deixa resgatar do sombrio e intolerável para se expressar como beleza artística. É isso o que resta da arte, segundo Nietzsche. Esse é o título do penúltimo dos fragmentos que formam esse capítulo sobre a arte em Humano, demasiado humano, o § 222:

\begin{abstract}
O que resta da arte. - É verdade que, existindo certos pressupostos metafísicos, a arte tem valor muito maior; por exemplo, quando vigora a crença de que o caráter é imutável e de que a essência do mundo se exprime continuamente em todos os caracteres e ações: a obra do artista se torna então a imagem do que subsiste eternamente, enquanto em nossa concepção o artista pode conferir validade à sua imagem somente por um período, porque o ser humano, como um todo, mudou e é mutável, e tampouco o indivíduo é algo fixo e constante."
\end{abstract}

O que faz a arte a não ser, justamente, criar e embelezar o que é mutável e humano, traduzindo os sentimentos mais próprios e mais verdadeiros de forma a fazer compreender não um sentido único e unilateral para a vida, mas a possibilidade de que ela contenha inúmeros sentidos. A arte, na medida em que olha a vida de frente, compreende a experiência existencial e ajuda a ver que mesmo ali, onde há dor, sofrimento, desilusão, horror, temor e morte, mesmo aí, há vida e porque é assim, há beleza, há força afirmativa, há vontade de dizer Sim: "Antes de tudo, durante milênios ela nos ensinou a olhar a vida, em todas as formas, com interesse e prazer, e a levar nosso sentimento ao ponto de enfim exclamarmos: 'seja como for, é boa a vida'". (HDH, 222)

É essa a lição da arte que todo artista deve recolher. Ela é o canal pelo qual a vida passa naquilo que ela tem de mais humano, demasiado humano. E porque é tão humana, a vida às vezes também aparece como desumana, cruel, plena, injusta, ilógica, caótica, sem sentido. A arte verdadeira é aquela que se deixa fecundar pela experiência existencial de um indivíduo e de um povo. É aí que ela se faz sua intérprete, uma locução primordial que faz ver que, apesar de tudo, há prazer na existência. Esse é o resultado a que Nietzsche chega, no caso da arte, com a utilização de seu procedimento psicológico. 


\section{Uma filosofia da inocência}

Com esse processo, Nietzsche se contrapõe a uma das questões mais importantes de toda a história da moral, desde Agostinho até Schopenhauer (esse último, considerado por Nietzsche como "antesala do cristianismo" - KSA 8, 30 [9], de 1878, p. 523), representantes da moral da compaixão. Afinal, "a premissa falsa de toda moral é o erro de que o homem age livremente e é responsável" (KSA 8, 23 [78], de 1876-1877, p. 429). É isso o que torna por vezes "desagradável" a observação psicológica e faz esse conhecimento perigoso, justamente a descoberta de que os atos não são conhecidos jamais e por isso não podem ser moralizados: "Não é justamente isso a 'terrível' verdade: que o que se pode saber de uma ação não basta jamais para fazê-la, que a ponte do conhecimento ao ato não foi lançada nem uma vez até hoje? Os atos não são jamais aquilo que nos parecem ser!" (A, 116). Só o procedimento fisio-psicológico pode desvendar essa "história" porque o que faz o indivíduo culpado é uma crença nascida de uma fraqueza frente à vida: "porque o homem se considera livre, não porque é livre, ele sofre arrependimento e remorso" (HH I, 39).

No $\S 99$ de Humano, Demasiado Humano Nietzsche volta a esse assunto, tratando do que há de inocente nas chamadas más ações: "As más ações que atualmente mais nos indignam baseiam-se no erro de que o homem que as comete tem livre-arbítrio, ou seja, de que dependeria do seu bel-prazer não nos fazer esse mal". Toda má ação só é assim caracterizada porque se parte da crença (errônea) no livre-arbítrio. Se não há liberdade na ação então a moral não pode mais avaliar algo bom ou mau: tudo passa a ser inocente irresponsável. Ora, Nietzsche não está querendo, com isso, negar a moral ou implantar um reino de irresponsabilidade. Ao contrário, sua tarefa é desvelar a moral como erro e disso dar-Ihe "ciência". O erro precisa ser reconhecido. É a isso que o procedimento de dissecação psicológica conduz. O que se revela a partir de então, não é um humano que pode ser punido ou responsabilizado: "a besta que existe em nós quer ser enganada; a moral é mentira necessária, para não sermos por ela dilacerados" ( $\mathrm{HH} \mathrm{I}, 40)$. O que Nietzsche pretende evitar e denunciar é que esses erros e mentiras sejam elevados como verdade absoluta e inquestionável.

Essas teses estão baseadas na ideia de que "o intelecto é a ferramenta no nosso instinto e nada mais, ele nunca se torna livre." (KSA 9, 3 [98], de 1880, p. 73) e por isso, tem como base a crítica de Nietzsche à hipertrofia da razão no mundo ocidental e ao reconhecimento dos erros por ela estabelecidos, entre os quais a ideia de que há um sujeito livre por trás das ações, quando na verdade, existem apenas pulsões em fluxo contínuo. Em Aurora, § 9, Nietzsche declara que "o homem livre é não-moral, porque em tudo quer depender de si e não de uma tradição". Isso significa que o 
indivíduo cuja autoafirmação se dá para além da moralidade (ela mesma nada mais do que um preconceito) deve romper com esses procedimentos incriminatórios da moralidade do costume, que exigia que "alguém observasse os preceitos sem pensar em si como indivíduo" ( $A, 9)$. Na moralidade do costume "o indivíduo deve sacrificar-se" em nome do todo e "cada ação individual, cada modo de pensar individual provoca horror" fazendo com que "o horizonte dos melhores tornou-se ainda mais sombrio do que deveria ser", já que toda originalidade e criatividade, segundo Nietzsche, é negada. A negação de si mesmo só pode fundar uma moral doentia, de personagens enfraquecidos - uma moral que "adquiriu máconsciência" na medida em que se pautou por uma negação desses instintos criadores no indivíduo, acentuando sua necessidade de adaptação. Toda a "causalidade do acontecer" foi interpretada como punição e não como inocência, a vida mesma como punição (cf. A, 14). Nietzsche chega a falar da "loucura" como aquela que "abre alas para a nova ideia", ou seja, está ligada ao exercício de rompimento com a moralidade estabelecida porque torna único e incompreendido, algo que tira o remorso da moral e devolve a inocência (cf. GC 125). Ter "fé em si mesmo" e ser "mais do que a lei" é a regra que brota desse exercício de afirmação de si mesmo descoberto pelo procedimento fisio-psicológico, cujo resultado mais importante é a afirmação da inocência do devir. Ora, é essa justamente a premissa inicial do projeto de uma ética da amizade: ela exige a afirmação de si para que a relação com o outro seja guiada pela saúde e pela higiene necessária para que a vida se fortaleça na afinidade e na disputa entre indivíduos fortes. A afirmação de si faz romper com o cânone da obediência ao valor externo guiado pelos interesses gregários representado pelo ethos porque nele se efetiva o pathos de vivências próprias, incomunicáveis e portanto, intransferíveis, definitivamente únicas e próprias (não podem ser seguidas por outros). O projeto da ética da amizade aparece como o meio e o espaço para o fortalecimento da energia vital de cada indivíduo - e isso o torna um fora da lei sob a perspectiva gregária.

Por isso, para Nietzsche, a revelação feita pela análise fisiopsicológica é que o erro não é só a afirmação de que "eu sou responsável", mas também o mesmo que se revela por sua antítese: "eu não sou, mas alguém deve ser" (OS, 33) - ou, poderíamos acrescentar, que alguma coisa deve ser. Ou seja, Nietzsche identifica na condenação e moralização do devir não mais do que um reflexo da necessidade de culpabilização e da crença no livre-arbítrio. Com isso se introduz "os conceitos morais no devir", como expressa uma variante do mesmo aforismo no projeto do manuscrito de Nietzsche: “Mas alguém deve ser pecador: se é impossível e não se permite acusar e julgar o indivíduo, essa pobre onda na ondulação necessária do devir, pois bem, seja o pecador a ondulação mesma, o devir; aqui 
está a livre vontade, aqui cabe acusar, condenar, expiar e purgar. [...]" (OS, 33). A psicologia desvenda como, então, a própria vida, enquanto caracterizada pelo fluxo constante, inocente e múltiplo do devir, passa a ser moralizada e culpada, e como essa condenação fornece as bases para a negação metafísica da existência a partir da invenção dos ultramundos.

A filosofia praticada por Nietzsche pretende, assim, "livrar paulatinamente" o humano desse "sentimento fastidioso" de "remorso e tormentos da consciência depois do ato, pois todo ato era completamente inevitável. A atitude filosófica é um fatalismo frio com respeito a todo o passado" (KSA 8, 19 [39], de 1876, p. 339). Aliás, é bom lembrar, Nietzsche, na curiosa lista dos 10 mandamentos do espírito livre, apresentado em KSA 8, 19 [77] (de 1878, p. 348), expressa a seguinte assertiva: "Não te arrependerás de um delito, mas, em compensação, farás uma obra boa a mais". Ou seja, a sua moral não é negativa da moral e nem uma mera inversão da moralidade vigente, como já antecipamos na introdução desse trabalho. Ao contrário, trata-se de uma moral afirmativa, de libertação do indivíduo (e do mundo), para que ele não permaneça submetido à culpa e ao remorso, mas crie, afirme, faça algo bom algo que favoreça a vida.

Em decorrência dessa crítica à distinção entre o indivíduo e a sua ação cuja expressão é a culpabilização do humano e do mundo, leva também à crítica à noção do perdão, porque, pergunta Nietzsche em referência às palavras de Jesus (Lucas 23, 24): "Como se pode perdoar-Ihes se eles não sabem o que fazem?" (AS, 68). A análise da ideia de perdão leva Nietzsche à análise psicológica do próprio Cristo, em sua perspicácia psicológica de si mesmo "(ou, como ele se expressava: a Deus)" (AS, 81). Em outras palavras: se o humano não é livre, ele não é responsável. Se ele não é responsável, ele não pode ser culpado e, portanto, também não pode ser perdoado.

Nietzsche reconhece que o estudo das "coisas morais" abre um "imenso campo de trabalho": "Todas as espécies de paixões têm de ser examinadas individualmente, perseguidas através de tempos, povos, grandes e pequenos indivíduos." $(\mathrm{GC}, 7)^{12}$. Nietzsche explicita n'A Gaia Ciência o mesmo procedimento utilizado nas outras duas obras desse período, ou seja, a história das coisas morais, a sua aparição como fenômenos humanos.

O resultado alcançado pela fisio-psicologia é a interpretação da inocência e da necessidade de todas as ações individuais, já que nesse campo reina o acaso, em contraposição às teses da moral da compaixão: "Na causação involuntária de danos não pode, naturalmente, haver o imoral; nela governa o acaso. [...] Quando não sabemos o mal que faz uma ação, ela não é uma ação maldosa: a criança não é maligna nem perversa com os animais: ela os investiga e os destrói como um brinquedo. Mas alguma vez se sabe 
inteiramente quanto mal faz uma ação a um outro ser?" (HH I, 104). Como toda ação ocorre para promover o prazer no indivíduo (o que é reconhecido por Nietzsche como "sentimento do próprio poder" e ainda como sentimento da "intensidade da própria excitação"), ele encontra na base das ações sempre a busca pelo bem-estar individual como característica de expansão da vida: essa é a premissa da nova moralidade, porque ela é a proposição inicial da própria vida ("Sem prazer não há vida; a luta pelo prazer é a luta pela vida"). A isso ele chama "teoria da completa irresponsabilidade" (HH I, 105) e mesmo da "inocência": "a total irresponsabilidade do homem por seus atos e seu ser é a gota mais amarga que o homem do conhecimento tem de engolir" (HH I, 107), porque o desejo de autofruição do indivíduo está na base de todos os sentimentos morais. Esse é o reino da completa necessidade da ação em busca da afirmação da vida: "Tudo é necessidade - assim diz o novo conhecimento" (HH I, 107). E isso justamente porque "tudo é inocência e o conhecimento é a via para compreender essa inocência". A tarefa do conhecimento (da filosofia fisio-psicológica praticada por Nietzsche) é desvelar essa condição primeira da moralidade. Não à toa, a última afirmação do segundo livro de Humano, Demasiado Humano alude ao fundo mutável e oscilante donde toda moral advém: "Tudo no âmbito da moral veio a ser, é mutável, oscilante, tudo está em fluxo, é verdade: - mas tudo se acha também numa corrente: em direção a uma meta" (HH I, 107). A meta admitida por Nietzsche nesse momento não é metafísica e não é outra a não ser a criação do "homem sábio e inocente", do qual o "homem" tolo da moral vigente não é senão o "precursor".

Observa-se como a afirmação da necessidade do vir-a-ser torna-se a premissa básica desvelada pela análise fisio-psicológica de Nietzsche e é ela que leva o humano de volta para si mesmo, por ela "o homem sente que de novo ama a si mesmo" ( $\mathrm{HH} \mathrm{I,} \mathrm{134)} \mathrm{porque} \mathrm{retoma} \mathrm{a} \mathrm{sua}$ inocência: "Se, por fim, a pessoa conquistar e incorporar totalmente a convicção filosófica da necessidade incondicional de todas as ações e de sua completa irresponsabilidade, desaparecerá também esse resíduo de remorso" (HH I, 133). A interpretação falsa e "não científica" oferecida pelo cristianismo a respeito da existência, do humano e da natureza, é desvendada por Nietzsche para devolver ao humano a liberdade, a leveza e a coragem frente à vida. É esse o processo de conquista daquilo que ele chama de grande saúde: ao contrário dos narcóticos cristãos, o filosofar fisio-psicológico de Nietzsche abre a possibilidade de criação de novos valores que afirmem a vida. Voltando a sentir-se como uma criança no jardim do paraíso, o humano retoma sua capacidade de criação e de afirmação da vida.

$\mathrm{Na}$ conjuntura de sua análise fisio-psicológica dos sentimentos morais, Nietzsche faz ver que a moralidade (em sentido tradicional), 
ao invés de valorizar esse indivíduo criativo em sua inteireza, implementou um processo de divisão do indivíduo, por negar-lhe a possibilidade de pensar em si mesmo, para fazê-lo agir sempre em função do próximo: "Não está claro que em todos esses casos o homem tem mais amor a algo de si, um pensamento, um anseio, um produto, do que a algo diferente de si, e que ele então divide seu ser, sacrificando uma parte à outra?" (HH I, 57). A psicologia de Nietzsche critica na ética da compaixão o seu empenho no sacrifício de si em função do outro: para o filósofo alemão a moral da compaixão tem como alicerce justamente esse alheamento de si mesmo, já que a base do altruísmo é essa entrega ao serviço de um outro. Ora, na verdade Nietzsche mostra que isso é quase "anti-natural", no sentido de que toda a ação humana está baseada naquele "fundo egoísta" de desejo, impulso e anseio que é próprio de cada pessoa.

\section{Referências Bibliográficas}

ANDLER, Charles. Nietzsche, sa vie e sa pensée. Lés précurseurs de Nietzsche. Paris: Gallimard, 1958.

BLONDEL, Eric. Nietzsche, le corps et la culture. Paris: PUF, 1986. BOURGET, Paul. Essais de Psychologie contemporaine. Études littéraires. Edition établie et prefacée par André Guyaux. Paris: GALLI MARD, 1993. (Col. Tel).

CAMPIONI, Giuliano. Les dieux et la décadence. In: - Les lectures francaises de Nietzsche. Paris: Presses Universitaires de France, 2001. P. 187-227.

BRUSOTTI, Marco. Die Leidenschaft der Erkenntnis. Philosophie und ästhetische ebensgestaltung bei Nietzsche von Morgenröthe bis Also sprach Zarathustra, Berlin/New York: de Gruyter, 1997.

CECCHINI, Antonio. II “divenire innocente" in Friedrich Nietzsche. Roma: Pubblicazione del Pontifício Seminário Lombardo in Roma, 2003. (Col. Dissertatio, Series Roma, 38.) P. 167-209.

FINK, Eugen. La filosofía de Nietzsche. Versión española de Andrés Sánchez Pascual. Madrid: Alianza Editorial, 1989.

GERHARDT, Volker. The body, the Self, ad the Ego. In: PEARSON, Keith Ansell (Ed.). A Companion to Nietzsche. Oxford /Malden /Victoria: Blackwell Publishing, 2006, p. 273-295.

GIACÓIA JÚNIOR, Oswaldo. Nietzsche como psicólogo. São Leopoldo: Editora Unisinos, 2006. (Col. Focus, 6)

MARQUES, António. A filosofia perspectivista de Nietzsche. São Paulo: Discurso editorial; Ijuí: Editora Unijuí, 2003. (Col. Sendas e Veredas).

. Para uma genealogia do perspectivismo. In: NIETZSCHE, F. Sujeito e Perspectivismo. Selecção de textos de Nietzsche sobre teoria do conhecimento. Lisboa: Publicações Dom Quixote, 1989, p. 11-61. 
NIETZCHE, F. Além do Bem e do Mal. Prelúdio a uma Filosofia do Futuro. Trad. de Paulo César de Souza. São Paulo: Cia. das Letras, 2. ed., 2002.

Assim Falou Zaratustra. Um livro para todos e para ninguém. 15a ed. Trad. de Mário da Silva. Rio de Janeiro: Civilização Brasileira, 2006.

Aurora. Reflexões sobre os preconceitos morais. Trad. de Paulo César de Souza. São Paulo: Cia. das Letras, 2004.

. Ecce Homo. Como alguém se torna o que é; Trad., notas e posfácio Paulo César de Souza. São Paulo: Companhia das Letras, 1995. 2a ed.; 3a reimpressão.

. Genealogia da Moral. Uma polêmica. Trad. de Paulo César de Souza. São Paulo: Cia. das Letras, 2002.

. Humano, Demasiado Humano. Um livro para espíritos livres. Trad. de Paulo César de Souza. São Paulo: Cia. das Letras, 2000 (Vol. I) e 2008 (Vol. II).

Obras incompletas. Trad. Rubens Rodrigues Torres Filho. São Paulo: Abril Cultural, 1983. (Col. Os Pensadores).

Sämtliche Briefe. Kritische Studienausgabe (KSB). Herausgegeben von Giorgio Colli und Mazzino Montinari. München/Berlin/New York: dtv/Walter de Gruyter ; Co., 1986. (8 Bänden).

Sämtliche Werke. Kritische Studienausgabe (KSA). Herausgegeben von Giorgio Colli und Mazzino Montinari. München/Berlin/New York: dtv/Walter de Gruyter ; Co., 1988. (15 Einzelbänden).

ONATE, Alberto Marcos. Entre eu e si ou a questão do humano na filosofia de Nietzsche. Rio de Janeiro: 7Letras, 2003.

VOLPI, Franco. O Niilismo. Trad. Aldo Vanucchi. São Paulo: Edições Loyola, 1999. (Col. Leituras filosóficas).

\section{Endereço para correspondência}

J elson Roberto de Oliveira

Pontifícia Universidade Católica do Paraná, Centro de Teologia e Ciências Humanas Curso de Filosofia, Rua Imaculada Conceição, 1155, Prado Velho, CEP 80215-901, Curitiba-PR, Brasil.

Endereço eletrônico: jelsono@yahoo.com.br

Recebido em: 14/04/2009

Aceito para publicação em: 27/10/2009

Acompanhamento do processo editorial: Adriana Benevides Soares

\section{Notas}

* Doutor em História da Filosofia Moderna e Contemporânea pela Universidade Federal de São Carlos - UFSCar 
1 Nesse artigo usaremos as siglas convencionais para citação dos escritos de Nietzsche: NT (O Nascimento da Tragédia); HH I (Humano, Demasiado Humano, vol. I); OS (Humano, Demasiado Humano II: Miscelânea de opiniões e sentenças); AS (Humano, Demasiado Humano II: O andarilho e sua sombra); A (Aurora); GC (A Gaia Ciência); KSA (Sämtliche Werke. Kritische Studienausgabe - edição crítica em 15 volumes organizada por Giorgio Colli e Mazzino Montinari); ZA (Assim Falou Zaratustra); BM (Além de Bem e Mal); GM (Para a Genealogia da Moral); EH (Ecce Homo).

2 Expressão também presente em ZA, I, Dos mil e um alvos. Segundo Rubens Torres Filho, na sua tradução da obra de Nietzsche (Col. Os Pensadores), "na origem da palavra Mensch, mannisco, substantivação do velho-alto-alemão mennisc (humano), encontra-se o radical indogermânico men (pensar), o mesmo que em latim deu mens (mente) e mensurare (medir). Talvez Nietzsche se refira a este último sentido, tanto mais que 'pensar' guarda lembrança de: tomar o peso, ponderar. Schätzen por: estimar, avaliar, apreciar, daí Schätzende, o que estima, o taxador" (NIETZSCHE, 1978, p. 233 ). É bom lembrar que a própria ideia de moralidade em Nietzsche não é mais do que um processo de avaliação realizado pelo "homem" a partir do "valor da vida": "entenda-se moral como a teoria das relações de dominação sob as quais se origina o fenômeno vida" (BM, 19). Por outro lado, lembrando a origem latina da palavra homem (humanus e homo remeteria a humus, ou seja, terra), ou seja, aquele "nascido da terra" explica a insistência por parte de Nietzsche a respeito da ascensão de uma moral que reconduza o homem de volta à terra, que mantenha uma fidelidade à terra a fim de que "a terra um dia se torne do além-do-humano" (ZA, Prefácio, 9).

3 Em O Andarilho e sua sombra, § 214, se lê: "Quando lemos Montaigne, La Rochefoucauld, La Bruyère, Fontenelle (sobretudo os Diálogos dos mortos), Vauvenargues, Chamfort, se está mais próximo da Antiguidade do que não importa qual grupo de seis autores de outras nações. Graças a estes seis escritores o espírito dos últimos séculos da era antiga é revivido de novo; reunidos formam um elo importante na grande corrente contínua do Renascimento. Seus livros se elevam além das mudanças de gosto nacionais e das colorações filosóficas, nas quais agora todo livro costumeiramente reluz e deve reluzir, para tornar-se conhecido: eles contêm mais pensamentos efetivos do que todos os livros dos filósofos alemães conjuntamente". E ainda em HHI, 36: "La Rochefoucauld e outros mestres franceses do estudo da alma (aos quais recentemente se juntou um alemão, o autor das Observações psicológicas) parecem atiradores de boa mira que acertam sempre no ponto escuro - mas no escuro da natureza humana. Sua destreza provoca admiração, mas afinal um espectador que seja conduzido não pelo espírito da ciência, mas pelo espírito humanitário, amaldiçoará uma arte que parece plantar na alma humana o gosto pela diminuição e pela suspeita".

${ }^{4}$ Para essa discussão, cf. GIACÓIA JúNIOR, 2006, obra na qual se encontram consolidadas os principais elementos que definem a importância de Nietzsche como psicólogo, demonstrando como o filósofo alemão se distancia da noção corrente de psicologia para se anunciar como o primeiro psicólogo, o autor de uma "grande psicologia".

${ }^{5}$ Ver a esse respeito A Gaia Ciência, 370.

“"Quem, antes de mim, foi entre os filósofos psicólogo, e não antes o oposto, um 'charlatão superior', um 'idealista'? Antes de mim, ainda não havia psicologia alguma. - ser aqui o primeiro pode constituir um anátema, é em todo o caso um destino: pois também se despreza como o primeiro... O nojo do homem, eis o meu perigo..." (EH, Porque sou um destino, 6)

${ }^{7}$ A esse respeito, cf. minha tese de doutoramento intitulada "Para uma ética da amizade em Friedrich Nietzsche" (São Carlos, UFSCar, 2009).

8 Der Philosoph als Arzt der Cultur: expressão usada desde os escritos de juventude, como atesta um fragmento do Livro do Filósofo (publicação inacabada e 
póstuma), presente em KSA 7, 23[15], de 1872-1873, p. 545). A expressão seria contraposta ao filósofo como "envenenador da cultura" (der Philosoph der Giftmischer der Kultur). Ou seja, se Platão é o envenenador, pela oposição dos instintos, Nietzsche busca o filósofo como o médico, o que reintegra o sentido trágico-artístico à existência.

${ }^{9}$ O seu interesse, entretanto, é bem mais antigo, remetendo a 1866, quando ele tem acesso à obra de Friedrich Albert Lange, Geschichte des Materialismus. Além disso, segundo relata ANDLER (1958, II, p. 328), Nietzsche lera várias obras sobre o assunto, entre as quais: Entstehung und Begriff der Naturhistorichen Art, de Naegeli publicada em 1865 e Descendenzlehre und Darwinismus de Oskar Schmidt, publicada em 1873. Na sua crítica ao darwinismo obteve ampla contribuição de seu colega Ludwig Rütimeyer, da Universidade de Basileia. Outras fontes de Nietzsche sobre o assunto, assinaladas por Colli e Montinari na sua organização dos textos nietzscheanos, foram: Der Kampf der Theile im Organismus. Ein Beitrag zur Vervollständigung der mechanischen Zweckmässigkeitslehre, de Wilhelm Roux, publicada em 1881; Biologische Probleme, zugleich als Versuch zur Entwicklung einer rationellen Ethik, de William Henry Rolph, também publicada em 1881; Lehrbuch der Physiologie, de Michael Foster, de 1881; Untersuchungen über das Gehirn, de Eduard Hitzig, de 1874); Phisiologie des Passions, de Charles Letourneau, pubicado em 1868); Der thieriche Wille, de Georg Heinrich Schneider, de 1882; Untersuchungen über den Erregungsprozess im Muskel - und Nervensystem, de Ernst Heinrich Weber, de 1870.

${ }^{10}$ Para um debate mais aprofundado sobre a relação entre fisiologia e biologia e dessas com a cultura, ver a obra de Wilson Antonio Frezzatti Junior, A Fisiologia de Nietzsche: a superação da dualidade cultura/biologia (2006).

${ }^{11}$ Entre os intérpretes de Nietzsche que trataram dessa questão destacam-se J ean Granier (1966) para quem o corpo possibilita relacionar o problema do ser com o vir-a-ser em Nietzsche; Eric Blondel (1986) que assinala o corpo como metáfora da interpretação em Nietzsche; e Michel Haar (1993) destaca de que forma o corpo serve de instrumento para a quebra da noção de sujeito na obra de Nietzsche.

12 Nesse fragmento, entre essas "coisas humanas, demasiado humanas" que são apontadas como objeto da pesquisa, Nietzsche coloca a amizade, perguntando: "Já foi mostrada a dialética do casamento e da amizade?" E conclui explicitando como à ciência ainda resta essa necessidade de experimentação, "séculos de experimentação". Isso porque, enquanto experimento, a amizade não pode ser conhecida a não ser a partir das vivências de cada indivíduo: “Creiam, amigos, a minha desrazão / Não foi para mim uma maldição! / O que eu acho, o que eu busco -, Já se encontrou em algum livro?", canta Nietzsche no Epílogo de Humano, Demasiado Humano. 